\title{
Comparison of cell-wall teichoic acid with high-molecular-weight extracellular slime material from Staphylococcus epidermidis
}

\author{
M. HUSSAIN, J. G. M. HASTINGS* and P. J. WHITE $\dagger$
}

Department of Molecular Biology and Biotechnology, The University, Western Bank, Sheffield S10 2TN and "Department of Clinical Microbiology, The Queen Elizabeth Hospital, Queen Elizabeth Medical Centre, Birmingham B15 2TH

\begin{abstract}
Summary. Extracellular high-mol.-wt material was separated from liquid cultures of Staphylococcus epidermidis. This material contained protein $c .20 \% \mathrm{w} / \mathrm{w}$ and polysaccharide c. $80 \% \mathrm{w} / \mathrm{w}$. The polysaccharide was isolated by gel and ion-exchange chromatography and contained glycerol phosphate, glucose, $\mathrm{N}$-acetylglucosamine, and $\mathrm{D}$-alanine. Cell-wall teichoic acid was isolated from strain RP-62A and had a similar composition.
\end{abstract}

\section{Introduction}

Coagulase-negative staphylococci (CNS) are an important cause of septicaemia in patients with haematological and other malignancies and in patients with implanted medical devices such as intravascular catheters, orthopaedic appliances and artificial heart valves. ${ }^{1-4}$ Some strains of CNS attach to solid surfaces and form adherent microcolonies by cell division. Further multiplication results in the development of a biofilm. The ability to adhere to foreign bodies and to produce extracellular slime during the course of colonisation is thought to be important in the genesis of infections associated with implants and invasive techniques. ${ }^{5-8}$

Recently, we showed that most of the extracellular high-mol.-wt material formed by CNS in a chemicallydefined medium is a single polymer, ${ }^{9}$ containing glycerol phosphate, glucose, glucosamine and alanine. The presence of these components strongly suggests that the polymer is a teichoic acid and in this study this extracellular polymer was compared with teichoic acid isolated from staphylococcal cell walls.

\section{Materials and methods}

\section{Bacteria}

Eight strains of Staphylococcus epidermidis were used: strains RP-12, (ATCC 35983) and RP-62A (ATCC 35984) were obtained from the American Type Culture Collection, Rockville, MD, USA and have been reported previously as highly adherent, good

Received 30 Jan. 1992; accepted 18 Feb. 1992.

$\dagger$ Correspondence should be sent to Dr P. J. White. slime-producing strains. ${ }^{2}$ Strains C762, C1276, C1543 and A2057 were isolated from infected long intravenous catheters in the Bacteriology Department, Royal Hallamshire Hospital, Sheffield; strains C362 and $\mathrm{C} 988$ were skin isolates. Of the six latter strains only C762 and $\mathrm{C} 1543$ gave positive results in the tube adherence test. $^{2}$

All strains were gram-positive cocci and produced catalase but not coagulase. They were identified as $S$. epidermidis according to the scheme of Kloos and Schleifer ${ }^{10}$ by the API STAPH (API Grafton Way, Basingstoke, Hampshire) test kit.

Isolation and purification of extracellular high-mol.-wt carbohydrate polymer (EC) and the effect of alkali on EC

Isolation and purification of EC by gel, ionexchange and affinity chromatography were as described previously. ${ }^{9}$ In a teichoic acid, which EC is believed to be, $\mathrm{D}$-alanine is ester-linked and this bond is sensitive to mild alkali treatment. A sample of EC was incubated in $1 \mathrm{M}$ ammonia at $37^{\circ} \mathrm{C}$ for $3 \mathrm{~h}$. This alkali-treated material, untreated EC and D-alanine were then examined by paper chromatography (solvent, ethyl acetate:acetic acid:water, 3:3:1, v:v:v).

\section{Isolation of cell-wall teichoic acid}

For isolation of cell-wall teichoic acid, S. epidermidis strain RP-62A was grown in $4 \mathrm{~L}$ of the chemically defined medium HHW ${ }^{11}$ or Tryptic Soy Broth (Difco) in eight 2-L flasks, each inoculated with $5 \mathrm{ml}$ of an 18-h culture in the same medium and incubated on a rotary shaker $(200 \mathrm{rpm})$ at $37^{\circ} \mathrm{C}$ for $18 \mathrm{~h}$. Bacteria were removed from the medium by centrifugation for $15 \mathrm{~min}$ at $6000 \mathrm{~g}$ in an MSE Mistral 6L centrifuge at 
$4^{\circ} \mathrm{C}$. They were washed in glass-distilled water three times (half the original culture volume each time) by resuspending and re-centrifuging.

Bacteria were broken by the method of Huff et al. ${ }^{12}$ by shaking with glass beads in a Braun cell homogeniser (B. Braun, Melsungen AG, Germany). For the separation of walls by sucrose gradient centrifugation, the method of Yoshida et al. was used. ${ }^{13}$ Teichoic acid was extracted from cell walls by two methods: (i) Extraction with trichloroacetic acid by the method of Archibald et al. ${ }^{14}$ (ii) Digestion with lysostaphin + lysozyme. Cell walls $(1 \mathrm{mg} / \mathrm{ml})$ were suspended in $0.05 \mathrm{M}$ Tris- $\mathrm{HCl}, \mathrm{pH} \mathrm{7.4}$, containing $1.2 \mathrm{mM} \mathrm{Na}_{2}$-EDTA, $0.145 \mathrm{M} \mathrm{NaCl}$ and a few drops of toluene (as a preservative). The suspension was first digested with a mixture of lysostaphin (20 units $/ \mathrm{ml}$; from S. saprophyticus; Sigma) and lysozyme $(1 \mathrm{mg} /$ $\mathrm{ml}$; from chicken egg-white; Sigma) at $25^{\circ} \mathrm{C}$ for $3 \mathrm{~h}$ followed by trypsin $(950 \mu \mathrm{g} / \mathrm{ml}$; Sigma) for $4 \mathrm{~h}$ at $37^{\circ} \mathrm{C}$. After enzyme treatment the suspension was centrifuged at $32000 \mathrm{~g}$ for $30 \mathrm{~min}$ at $4^{\circ} \mathrm{C}$ and then passed through a $0 \cdot 22-\mu \mathrm{m}$ membrane filter (Millipore) to remove cell-wall fragments. Five volumes of ethanol were added to the filtrate. After standing overnight at $4^{\circ} \mathrm{C}$, the liquid was discarded and the precipitate was freeze-dried.

\section{Ion-exchange and affinity chromatography}

Teichoic acid isolated by either of the above procedures was fractionated by ion-exchange (DEAEcellulose) and affinity chromatography as described previously for the fractionation of EC. ${ }^{9}$

\section{Paper chromatography}

Before chromatography, samples of EC or cell-wall teichoic acid were hydrolysed by heating at $100^{\circ} \mathrm{C}$ for $3 \mathrm{~h}$ in $3 \mathrm{M} \mathrm{HCl}$ in a sealed tube. Hydrolysates were dried in a desiccator over silica gel and solid $\mathrm{NaOH}$ at room temperature, then twice moistened with water and dried again. Descending chromatography was done on Whatman No. 1 paper with one of the following solvents. ${ }^{15,16}$ (A) butan-1-ol:pyridine: water (6:4:3); (B) ethyl acetate:acetic acid:water $(9: 2: 2)$; (C) ethyl acetate : acetic acid: water (3:3:1); (D) butan1-ol: acetic acid: water $(8: 2: 2)$ (each v:v:v). Chromatograms were developed for $18-32 \mathrm{~h}$ and dried in a stream of cold air. Amino acids and amino sugars were detected by dipping the chromatograms in ninhydrin $0.25 \% \mathrm{w} / \mathrm{v}$ in acetone, followed by drying and heating at $105^{\circ} \mathrm{C}$ for $5 \mathrm{~min}$. For the detection of reducing sugars and their derivatives, alkaline silver nitrate was chiefly used. ${ }^{17}$ In some cases, to detect sugars, chromatograms were sprayed with $p$-anisidine hydrochloride (in butan-1-ol:ethanol:water, $4: 1: 1$, v:v:v) $3 \%$ and then heated at $105^{\circ} \mathrm{C}$ for $3-5 \mathrm{~min}$. For the detection of phosphate esters the method of Burrows was used, as described by Block et al. ${ }^{15}$ Chromatograms were sprayed with a mixture of perchloric acid $60 \%$
Table I. Enzyme assays

\begin{tabular}{|c|c|c|}
\hline Test & Enzyme(s) & $\begin{array}{c}\text { Reference } \\
\text { no. }\end{array}$ \\
\hline \multirow[t]{2}{*}{ Glucose } & $\begin{array}{l}\text { 1. Hexokinase (from baker's } \\
\text { yeast; Sigma) + glucose 6- } \\
\text { phosphate dehydrogenase } \\
\text { (from Torula yeast; Sigma) }\end{array}$ & 18 \\
\hline & $\begin{array}{l}\text { 2. Glucose oxidase (Sigma) } \\
\text { +peroxidase (Sigma) }\end{array}$ & 19 \\
\hline Glycerol-1-PO & $\begin{array}{l}\text { Glycerol phosphate } \\
\text { dehydrogenase (from rabbit } \\
\text { muscle; Sigma) }\end{array}$ & 20 \\
\hline D-Alanine & $\begin{array}{l}\text { Catalase (from mouse liver; } \\
\text { Sigma) + D-amino acid } \\
\text { oxidase (from porcine kidney; } \\
\text { Boehringer) }\end{array}$ & 21 \\
\hline
\end{tabular}

w/v: $1 \mathrm{M} \mathrm{HCl}$ :ammonium molybdate $4 \% \mathrm{w} / \mathrm{v}$ : water $(5: 10: 25: 60, v: v: v: v)$.

\section{Reactions with lectins}

A sample $(20 \mu \mathrm{l})$ of an aqueous solution of EC or teichoic acid $(5 \mathrm{mg} / \mathrm{ml})$ was mixed with $20 \mu$ l of lectin solution (used as obtained from the supplier without dilution) on a glass slide. Results were recorded after 1 min as - or,,++++++ according to the extent of clumping, as judged by eye. The lectins used were Concanavalin-A (specific for $\alpha$-D-glucose or $\alpha$-D-mannose) and Bandeiraea simplicifolia BS-II lectin (specific for $\mathrm{D}-\mathrm{N}$-acetylglucosamine); both were obtained from Sigma.

\section{Measurement of radioactivity on paper chromatograms}

Hydrolysates labelled with ${ }^{14} \mathrm{C}$ were applied to paper chromatograms as spots $4 \mathrm{~cm}$ apart; after development, each track was cut into strips $4 \mathrm{~cm}$ wide, and then into pieces every $1 \mathrm{~cm}$ down its length. Each $4 \times 1 \mathrm{~cm}$ piece was cut into quarters which were immersed together in $1 \mathrm{ml}$ of distilled water in a scintillation vial for the elution of radioactivity from the paper. After $1 \mathrm{~h}$, during which vials were shaken twice, $9 \mathrm{ml}$ of scintillation fluid "Safe Fluor S" (Lucan Lsc, Olen, Belgium) was added to each vial. After thorough mixing, radioactivity was measured in a Beckman 1801 liquid scintillation counter (Beckman Instruments, Fullerton, CA, USA).

\section{Chemical and enzyme analyses}

A summary of the methods of colorimetric, chemical and enzymic analysis used are given in tables I and II. ${ }^{18-32}$

\section{Gas chromatography}

For the analysis of lipids, dried samples $(500 \mu \mathrm{g})$ were hydrolysed with $0.1 \mathrm{ml}$ of methanolic- $\mathrm{KOH}$ 
Table II. Chemical analyses

\begin{tabular}{|c|c|c|c|}
\hline Substance assayed & $\begin{array}{l}\text { Compound used for } \\
\text { standard curve }\end{array}$ & $\begin{array}{l}\text { Range of } \\
\text { assay* }\end{array}$ & Reference no. \\
\hline \multicolumn{4}{|l|}{ Total carbohydrate } \\
\hline Phenol- $\mathrm{H}_{2} \mathrm{SO}_{4}$ & $\begin{array}{l}\text { Glucose, galactose, } \\
\text { mannose, ribose, } \\
\text { glucuronic acid }\end{array}$ & $0-0.3$ & 22 \\
\hline Cysteine- $\mathrm{H}_{2} \mathrm{SO}_{4}$ & All above & $0-0.2$ & 23 \\
\hline Sulphated $\alpha$-napthol & All above & $0-0.3$ & 24 \\
\hline Anthrone & Glucose, galactose & $0-0.4$ & 25 \\
\hline Hexosamine & Glucosamine. $\mathrm{HCl}$ & $0-0.6$ & 26 \\
\hline Uronic acids & Glucuronic acid & $0-0 \cdot 2$ & 27 \\
\hline Pentose & Ribose & $10-50 \mu \mathrm{g}$ & 25 \\
\hline Phosphorus & $\mathrm{KH}_{2} \mathrm{PO}_{4}$ & $0-0.05$ & 28 \\
\hline Protein & $\begin{array}{l}\text { Bovine serum albumin } \\
\text { (Sigma) }\end{array}$ & $0-100 \mu \mathrm{g}$ & 29 \\
\hline Glycerol & Glycerol & $2-60 \mu \mathrm{g}$ & 30 \\
\hline Amino acids & D-alanine & $0-0.4$ & 31 \\
\hline Amino sugars & Glucosamine. $\mathrm{HCl}$ & $0-100 \mu \mathrm{g}$ & 32 \\
\hline
\end{tabular}

* Range of assay in $\mu \mathrm{mol} /$ test unless stated otherwise.

(7 $\mathrm{M} \mathrm{KOH}$ : methanol, $7: 3, \mathrm{v}: \mathrm{v}$ ) in a water bath at $90^{\circ} \mathrm{C}$ for $1 \mathrm{~h}$. Methanol was evaporated under $\mathrm{N}_{2}$ and $0.8 \mathrm{ml}$ of concentrated $\mathrm{HCl}$ was added. To extract free fatty acids, petroleum ether was added and the top layer was removed; this process was repeated three times and these layers were mixed together and concentrated to $0.2 \mathrm{ml}$. Methylation was done by adding $0.1 \mathrm{ml}$ of $\mathrm{BF}_{3}$ (Sigma) in methanol 14\% w/v to the concentrate and heating at $60^{\circ} \mathrm{C}$ for $5 \mathrm{~min}$. After cooling, $0.2 \mathrm{ml}$ of distilled water was added and samples were extracted four times with $2 \mathrm{ml}$ of petroleum ether. Residual ether was removed with a stream of $\mathrm{N}_{2}$ and the sample was resuspended in $0.1 \mathrm{ml}$ of redistilled hexane. Two columns, SE-30 3\% and OV-17 3\%, were used in a Shimadzu GC-14A apparatus connected to a Shimadzu C-R5A Chromatopac integrator. Oven temperature was a constant $165^{\circ} \mathrm{C}$ and injector and detector temperature was $250^{\circ} \mathrm{C}$. Samples or standards $(1 \mu \mathrm{l})$ were injected into the column with a syringe (Hamilton Company, Reno, Nevada). A mixture of known fatty acid methyl esters $\left(\mathrm{C}_{10}-\mathrm{C}_{20}\right)$ was used as a control.

\section{Results}

\section{Analysis of high-mol.-wt carbohydrate from strain $R P-62 A$ grown in liquid medium $\mathrm{HHW}$}

Purified material isolated from Concanavalin-ASepharose 4-B contained glycerol phosphate, glucose, glucosamine and alanine, as determined by paper chromatography and gas chromatography. ${ }^{9}$ The relative proportions in the polymer were determined in freeze-dried material by chemical analysis and enzyme tests as shown in table III. Glucose was measured by two separate enzyme tests and the results of both assays were similar. $\alpha$-L-Glycerol phosphate was measured by enzyme assay with glycerokinase + glycerophosphate dehydrogenase and by the acetylacetone chemical assay. ${ }^{30}$ The enzyme assay was slow and the value calculated by the interpolation method was $1.87 \mu \mathrm{mol} / \mathrm{mg}$ of freeze-dried material. In the chemical assay there was a little interference from glucose; the colour developed with a glucose standard was $30 \% ; \beta$-glycerol phosphate was $10 \%$ of that of equimolar $\alpha$-glycerol phosphate. Some difficulty was encountered in measuring the D-alanine content by enzyme assay ( $D$-amino acid oxidase + catalase); the value calculated was $1.14 \mu \mathrm{mol} / \mathrm{mg}$. Since the only amino acid in the polymer was D-alanine, it was possible to use the modified ninhydrin assay for amino acids to estimate the alanine content. Glucosamine content of the polymer was measured by the methods of Levvy and McAllan, ${ }^{26}$ and of Cessi and Piliego (described by Stewart-Tull. ${ }^{32}$ ) Similar results were obtained with both chemical assays. Total phosphorus, as measured by the Ames method, was 5.2\% w/w. No fatty acids were found by gas chromatography.

\section{Identification of alanine}

The material eluted from Concanavalin-ASepharose 4-B with $0.1 \mathrm{M}$ methyl $\alpha$-D-glucoside in buffer was hydrolysed in $6 \mathrm{M} \mathrm{HCl}$ for $18 \mathrm{~h}$ in a sealed tube, and after removing acid was analysed by paper and thin-layer chromatography in two dimensions. A single ninhydrin-positive spot with an $R_{f}$ value corresponding to that of alanine was detected. L-Alanine and D-alanine markers moved the same distance on both chromatograms and, therefore, D-amino acid oxidase + catalase was used to identify the isomeric form of the alanine. The hydrolysate, D-alanine or Lalanine together with the hydrolysate, or D-alanine or L-alanine alone were treated separately with D-amino acid oxidase + catalase, and were then spotted on to a paper chromatogram that was developed in solvent $B$. Spots were revealed with ninhydrin $0.2 \%$ in acetone and were seen $158 \mathrm{~mm}$ from the origin in untreated hydrolysate, untreated D-alanine, untreated and 
Table III. Chemical analysis of EC from $S$. epidermidis RP-62A and teichoic acids isolated by trichloroacetic acid extraction or enzymic digestion of walls of $S$. epidermidis RP-62A

\begin{tabular}{|c|c|c|c|c|c|c|c|}
\hline \multirow{3}{*}{$\begin{array}{l}\text { Component } \\
\text { Glucose }\end{array}$} & \multicolumn{3}{|c|}{ Content $(\mu \mathrm{g} / \mathrm{mg})$ in } & \multirow{3}{*}{$\frac{\begin{array}{c}\text { Mol. wt of } \\
\text { polymer unit }\end{array}}{162}$} & \multicolumn{3}{|c|}{ Content $(\mathrm{mol} / \mathrm{mol}$ glycerol } \\
\hline & \multirow{2}{*}{$\frac{\mathrm{EC}^{*}}{165(1.02)}$} & \multicolumn{2}{|c|}{$\dagger$ Teichoic acid $\ddagger$} & & \multirow{2}{*}{$\begin{array}{l}\text { EC* } \\
0.45\end{array}$} & \multicolumn{2}{|c|}{$\dagger$ Teichoic acid $\ddagger$} \\
\hline & & $171(1.05)$ & $153(0.94)$ & & & 0.5 & 0.45 \\
\hline Glycerol & $167(2 \cdot 26)$ & $156(2 \cdot 10)$ & $154(2.08)$ & 74 & 1.00 & 1.00 & 1.00 \\
\hline D-Alanine & $81(1 \cdot 14)$ & $77(1.08)$ & $77(1.08)$ & 61 & 0.50 & 0.51 & 0.52 \\
\hline$N$-Acetylglucosamine & $38(0 \cdot 19)$ & $42(0.20)$ & $37(0 \cdot 18)$ & 203 & 0.08 & $0 \cdot 10$ & 0.08 \\
\hline Phosphate & $156(1.95)$ & $167(2.08)$ & $174(2 \cdot 17)$ & 80 & 0.86 & 0.99 & 1.04 \\
\hline
\end{tabular}

* EC eluted from Concanavalin-A-Sepharose 4-B column.

$\dagger$ Teichoic acid isolated after stirring cell walls in trichloroacetic acid $10 \%$ for $48 \mathrm{~h}$.

$\ddagger$ Teichoic acid isolated after digestion of the cell walls with lysozyme-lysostaphin.

() Values in brackets are $\mu \mathrm{mol} / \mathrm{mg}$.
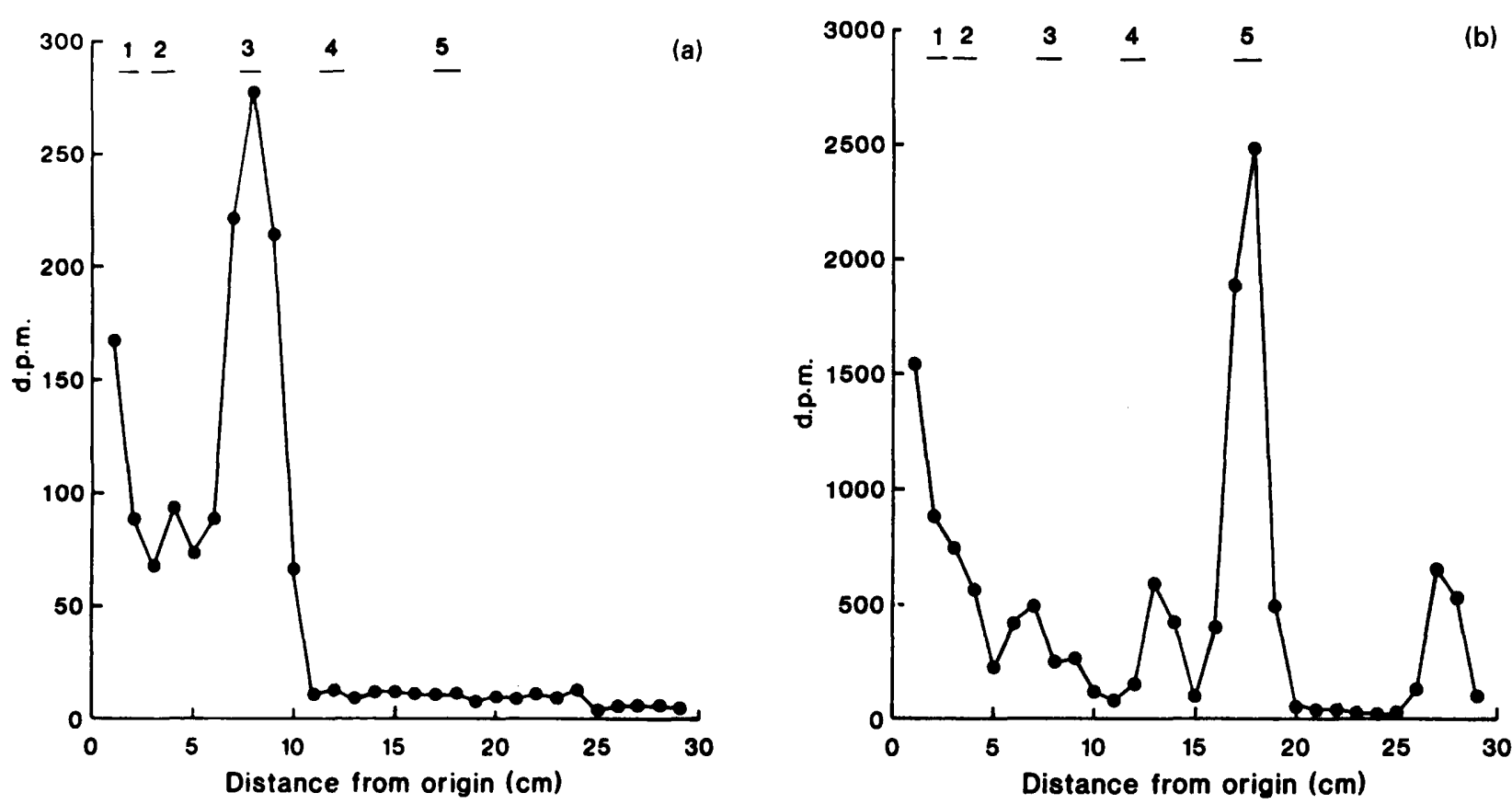

Fig. 1. Distribution of radioactivity on a paper chromatogram (solvent A) after hydrolysis $\left(3 \mathrm{M} \mathrm{HCl}\right.$ for $3 \mathrm{~h}$ at $100^{\circ} \mathrm{C}$ in a sealed tube) of material from $S$. epidermidis RP-62A, eluted from Concanavalin-A-Sepharose 4-B: (a) labelled with ${ }^{14} \mathrm{C}$ amino acid mixture; (b) labelled with ${ }^{14} \mathrm{C}$ glucose. Positions of marker compounds were: 1 , glycerol-1- $\mathrm{PO}_{4} ; 2$, glucuronic acid; 3 , alanine; 4 , glucosamine; 5 , glucose.

treated L-alanine. However, spots were absent from the hydrolysate (or D-alanine) treated with D-amino acid oxidase + catalase.

\section{Ester-linked D-alanine}

A round dark ninhydrin-positive spot with the $R_{t}$ value of $D$-alanine was revealed from alkali-treated EC (see Materials and methods). Only a light, elongated streak was present in untreated EC at the same $R_{f}$ value. A similar chromatogram stained with $p$-anisidine showed only one dark spot at the origin for both treated and untreated material. These results suggest the release of ester-linked alanine from the polymer, a characteristic of teichoic acids; the polymer itself was not broken down by the alkali.

\section{Reaction with lectins}

EC from four strains (RP62-A, RP-12, C762 and C1543), either crude or partially purified by DEAE- cellulose or affinity chromatography, was agglutinated by Concanavalin-A. This reaction was inhibited by either glucose or mannose $(0.5 \% \mathrm{w} / \mathrm{v}$ in the complete test mixture). EC from strains RP-62A, C1543 and C988, but not that from strain RP-12 was also agglutinated by $B$. simplicifolia lectin which is specific for $N$-acetylglucosamine. These positive reactions suggested the presence of both glucose and $N$ acetylglucosamine as free terminal groups.

Radiochemical studies of EC from several strains of $S$. epidermidis analysed by paper chromatography

The EC labelled with ${ }^{14} \mathrm{C}$ glucose or ${ }^{14} \mathrm{C}$ amino acids that had bound to Concanavalin-A-Sepharose 4-B was hydrolysed in $3 \mathrm{M} \mathrm{HCl}$ for $3 \mathrm{~h}$. Four chromatographic solvents (A, B, C and D) were used to resolve the acid-free hydrolysate. A small part of the hydrolysate and marker glycerol phosphate remained close to the origin in solvent $\mathrm{D}$. Since the spotted hydrolysate on paper was allowed to dry at room tem- 

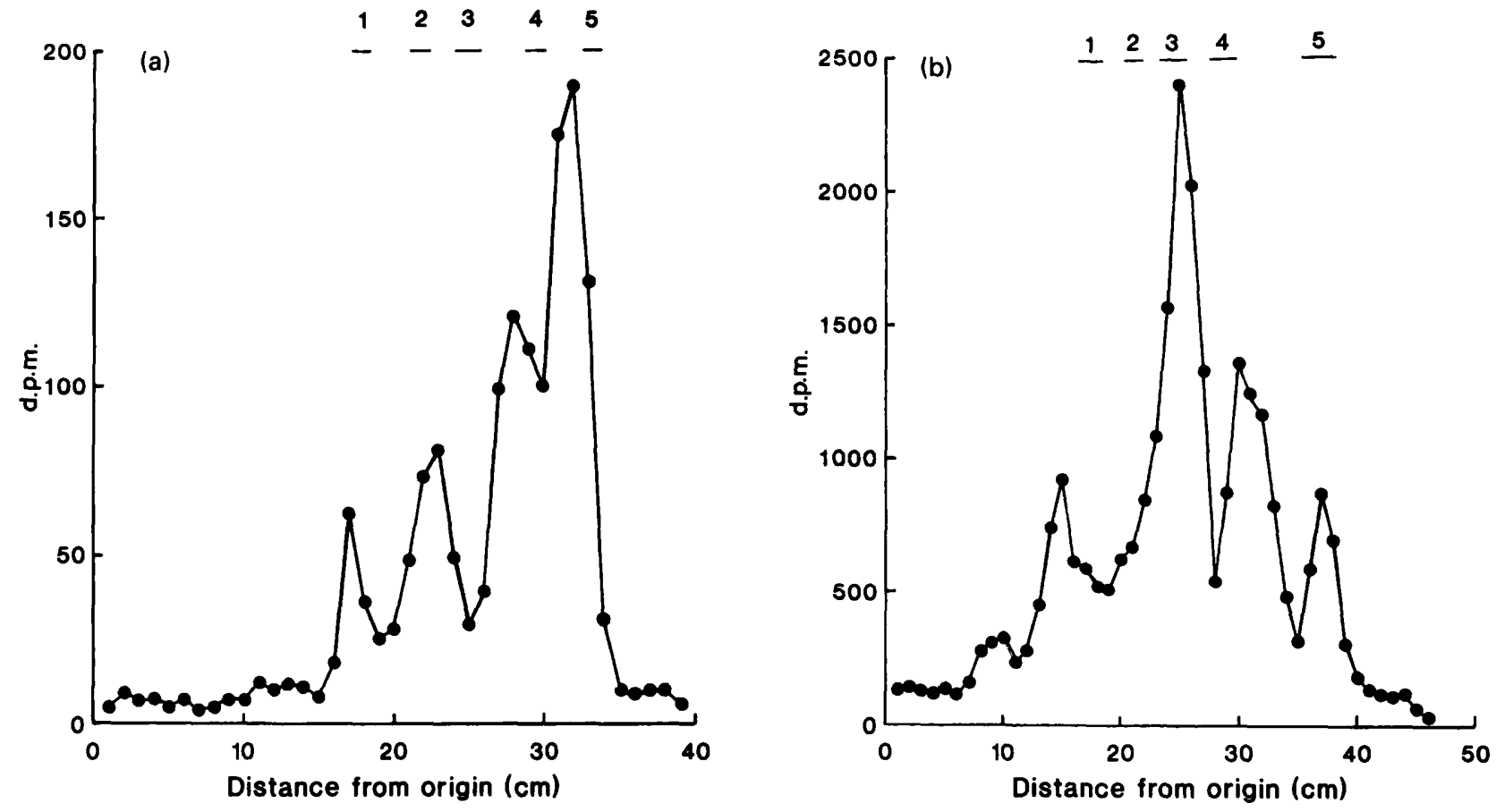

Fig. 2. Distribution of radioactivity on a paper chromatogram (solvent $\mathrm{B}$ ) after hydrolysis $\left(3 \mathrm{M} \mathrm{HCl}\right.$ for $3 \mathrm{~h}$ at $100^{\circ} \mathrm{C}$ in a sealed tube) of material from $S$. epidermidis RP-62A, eluted from concanavalin-A-Sepharose 4-B: (a) labelled with ${ }^{14} \mathrm{C}$ amino acid mixture; (b) labelled with ${ }^{14} \mathrm{C}$ glucose. Positions of marker compounds were: 1 , glucuronic acid; 2 , glycerol-1- $\mathrm{PO}_{4} ; 3$, glucose; 4, glucosamine; 5 , alanine.
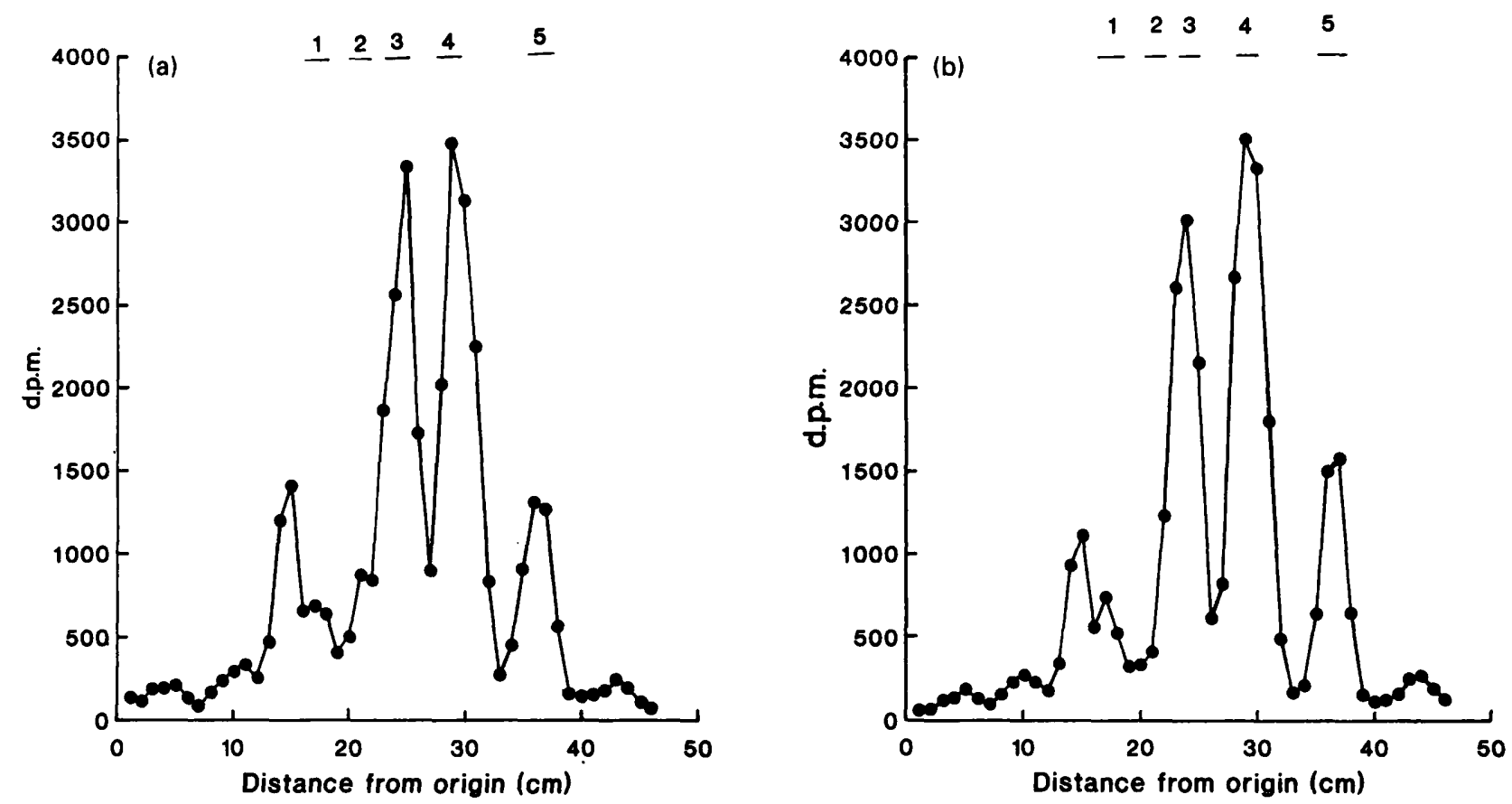

Fig. 3. Distribution of radioactivity from high-mol.-wt material labelled with ${ }^{14} \mathrm{C}$ glucose from two non-adherent strains of $S$. epidermidis on a paper chromatogram (solvent C) after hydrolysis in $3 \mathrm{M} \mathrm{HCl}$ for $3 \mathrm{~h}$ at $100^{\circ} \mathrm{C}$ in a sealed tube: (a) S. epidermidis C988; (b) S. epidermidis C362. Positions of marker compounds were: 1 , glucosamine; 2, glucuronic acid; 3, glucose; 4, glycerol-1-PO 4 ; 5 , alanine.

perature, it is unlikely that this immobility was due to fixation by heat. The best separation was achieved in solvent $\mathrm{C}$, but solvents $\mathrm{A}$ and $\mathrm{B}$ also resolved the hydrolysate to a lesser extent (figs. 1-3). The maximum labelling was seen in the peak representing alanine when EC was labelled with amino acids, and in the glucose peak when labelling was done with glucose. The other components in the hydrolysate were glycerol phosphate, glucosamine and a small spot close to the $\mathbf{R}_{\text {glucose }}$ value of glucuronic acid. The spots produced by markers did not coincide exactly with the respective radioactive peaks; this was probably due either to the number of different molecules in a hydrolysate interacting to give slightly decreased mobilities or because the distribution of radioactivity from a particular molecule would not necessarily be exactly matched by the position of the pieces into which the paper was cut.

Since good separation was achieved in solvent $\mathrm{C}$ it was used in subsequent studies with several strains. The crude EC from four adherent and four non- 
adherent strains was hydrolysed for $3 \mathrm{~h}$ in $3 \mathrm{M} \mathrm{HCl}$. Glucose, glycerol phosphate, alanine and glucosamine were found on chromatograms of EC from all the eight S. epidermidis strains.

\section{Comparison of cell-wall teichoic acid and EC from strain RP-62A}

The total EC material contained several proteins and a single carbohydrate polymer which was identified as teichoic acid. The failure to detect lipids by gas chromatography suggested that its origin was in the cell wall rather than in the membrane (as a lipoteichoic acid); therefore, cell-wall teichoic acid was isolated from strain RP-62A and compared with EC from this strain.

\section{Isolation of cell walls}

Phase-contrast microscopy and electronmicroscopy of a washed cell-wall preparation revealed at least $99 \%$ broken cells after 10 bursts, each of $30 \mathrm{~s}$, in a Braun disintegrator. Trypsin-digested cell walls were separated into three layers in a sucrose gradient: a layer at the bottom consisted of mainly cell walls clumped together, with a few unbroken cells; a middle layer, about $4 \mathrm{~cm}$ thick, contained only cell walls; and an upper layer comprised small fragments of broken walls. Approximately $280 \mathrm{mg}$ of cell walls (from the middle band) were isolated from $2 \mathrm{~L}$ of culture (equivalent to a density of $1.35 \mathrm{~g}$ dry weight of bacteria/L).

These cell walls were hydrolysed in $6 \mathrm{M} \mathrm{HCl}$ for $18 \mathrm{~h}$, and amino acids were separated by thin layer chromatography in two dimensions. Only alanine, glycine, glutamic acid and lysine were detected with ninhydrin, a clear indication of a pure cell-wall preparation. Isolated walls contained total phosphorus $2.8 \% \mathrm{w} / \mathrm{w}$ and total carbohydrate (by phenol$\mathrm{H}_{2} \mathrm{SO}_{4}$ assay) $11 \% \mathrm{w} / \mathrm{w}$.

\section{Isolation of cell-wall teichoic acid}

Freeze-dried cell walls in trichloroacetic acid $10 \%$ $\mathrm{w} / \mathrm{v}$ were stirred for $48 \mathrm{~h}$ and $60 \mathrm{mg}$ of teichoic acid was extracted from $265 \mathrm{mg}$ of walls. Neither lysozyme nor lysostaphin alone digested the walls to any significant extent but when both enzymes (lysozyme $1 \mathrm{mg}$ and lysostaphin 20 units $/ \mathrm{ml}$ of wall suspension) were added to a suspension of walls $(0.8 \mathrm{mg} / \mathrm{ml})$ adjusted to an $\mathrm{OD}_{550 \mathrm{~nm}}$ of 1.00 , the turbid suspension became clear $\left(\mathrm{OD}_{550 \mathrm{~nm}}\right.$ was $\left.0 \cdot 2\right)$ within $60 \mathrm{~min}$. The enzyme digest was loaded on to Sephadex G-50 to isolate the teichoic acid and the column was eluted with distilled water. Fractions were analysed for total phosphorus and for proteins (i.e., the enzymes used to digest the walls and any protein associated with the walls) by absorbance at $280 \mathrm{~nm}$. A peak was detected near the void volume with the phosphorus assay, but later fractions also contained protein. Separation of the remaining protein was achieved in the subsequent ion-exchange and affinity chromatography steps.

\section{Ion-exchange and affinity chromatography of cell-wall teichoic acid}

The teichoic acid isolated by enzyme digestion of walls also contained some protein that flowed straight through the DEAE-cellulose column with the loading buffer while teichoic acid eluted with $0.5 \mathrm{M} \mathrm{NaCl}$ in buffer. Teichoic acid isolated by enzyme digestion of walls was free of protein at this stage and the yield was $24 \% \mathrm{w} / \mathrm{w}$ of the dry cell walls compared with a yield of $22.6 \% \mathrm{w} / \mathrm{w}$ of dry cell walls by trichloroacetic acid extraction. The teichoic acid isolated by stirring the isolated walls with trichloroacetic acid bound to DEAE-cellulose and eluted as a single peak with $0.5 \mathrm{M} \mathrm{NaCl}$ in buffer, as detected by the phenol- $\mathrm{H}_{2} \mathrm{SO}_{4}$ assay for total carbohydrates.

The teichoic acid isolated by either method, eluted from DEAE-cellulose with salt, bound to Concanavalin-A-Sepharose 4-B and eluted as a single peak with $0.1 \mathrm{M}$ methyl $\alpha$-D-glucoside. This same material also showed binding to the lectin from $B$. simplicifolia BS-II and eluted with $0.1 \mathrm{M} N$ acetylglucosamine in buffer.

\section{Analysis of cell-wall teichoic acid}

Teichoic acid isolated by either of the above procedures was hydrolysed in $3 \mathrm{M} \mathrm{HCl}$ for $3 \mathrm{~h}$ and analysed by paper chromatography. Spots with $\mathbf{R}_{\text {glucose }}$ values close to those of glucose, glucosamine, glycerol phosphate and glucuronic acid were identified with $p$ anisidine or $\mathrm{AgNO}_{3}-\mathrm{NaOH}$. In another chromatogram, a spot of glycerol phosphate was disclosed with ammonium molybdate-perchloric acid- $\mathrm{HCl}$ mixture. The chromatogram stained with ninhydrin showed only one spot close to the alanine marker. Analysis with D-amino acid oxidase + catalase in combination with paper chromatography showed that all the alanine was the D-isomer. Enzyme assays for glycerol failed to detect any free glycerol, and teichoic acid isolated by the two procedures contained only glycerol phosphate. Results of estimations of different components of teichoic acids are presented in table III.

\section{Electrophoresis of teichoic acid and EC from strain $R P-62 A$}

Cell-wall teichoic acid, isolated either by trichloroacetic acid or enzyme digestion, and EC were electrophoresed on SDS gels ( $\mathrm{pH} \mathrm{8.3)} \mathrm{and} \mathrm{were} \mathrm{then} \mathrm{stained}$ with Alcian Blue for carbohydrates. Teichoic acid isolated by enzyme digestion of walls or EC migrated the same distance after $1.5 \mathrm{~h}$ at $100 \mathrm{~V}$ (a single band at $35 \mathrm{~mm}$; total gel length $65 \mathrm{~mm}$ ) but teichoic acid extracted by trichloroacetic acid treatment moved further, to $39 \mathrm{~mm}$. It is possible that some of the phosphodiester linkages in the polymer were broken 
down during extraction with trichloroacetic acid to cause a decrease in molecular size and hence greater mobility on the SDS gel.

\section{Discussion}

Crude EC and the purified materials eluted from DEAE-cellulose and affinity chromatography columns from all strains contained glycerol phosphate, Dalanine, glucose (except strain RP-12) and $N$ acetylglucosamine. Ester linking of D-alanine, the absence of lipids and the presence of constituent monomers in simple molar proportions, as detected by chemical analyses, strongly suggested that the isolated polymer was glycerol teichoic acid. Inhibition of the formation of EC by low concentrations of tunicamycin supports this view. ${ }^{33}$ The cell-wall teichoic acid isolated by enzyme digestion or trichloroacetic acid extraction of purified walls from strain RP-62A also contained glucose, glucosamine, glycerol phosphate and alanine, and these constituents were present in similar molar proportions to those detected in EC from strain RP-62A.

Radiolabelled material eluted from ConcanavalinA-Sepharose 4-B was hydrolysed in $3 \mathrm{M} \mathrm{HCl}$ for $3 \mathrm{~h}$ and separated into constituent monomers on paper chromatograms. Glucose, alanine, glycerol phosphate, glucosamine and a spot close to the $\mathbf{R}_{\text {glucose }}$ value of glucuronic acid were identified in material from several strains. More labelling was detected in the glucose spot

\section{References}

1. Bayston R, Penny SR. Excessive production of mucoid substance in Staphylococcus SIIA: a possible factor in colonisation of Holter shunts. Dev Med Child Neurol 1972;14 Suppl 27: 25-28.

2. Christensen GD, Simpson WA, Bisno AL, Beachey EH. Adherence of slime-producing strains of Staphylococcus epidermidis to smooth surfaces. Infect Immun 1982; 37 . 318-326.

3. Peters G, Locci R, Pulverer G. Adherence and growth of coagulase-negative staphylococci on surfaces of intravenous catheters. $J$ Infect Dis $1982 ; 146$ : 479-482.

4. Pulverer G, Pillich J. Pathogenic significance of coagulasenegative staphylococci. In: Finland M, Margret W, Bartmann K (eds) Bayer Symposium III, Bacterial infections : changes in their causative agents, trends and possible basis. Berlin, Springer-Verlag. 1971: 91-96.

5. Christensen GD, Barker LP, Mawhinney TP, Baddour LM, Simpson WA. Identification of an antigenic marker of slime production for Staphylococcus epidermidis. Infect Immun 1990; 58: 2906-2911.

6. Costerton JW, Marrie TT. The mode of bacterial growth on metal and plastic prosthesis that become foci of bacterial infections. Abstracts of the Annual Meeting of the American Society for Microbiology 1983: B183.

7. Costerton JW, Marrie TJ, Cheng K-J. Phenomena of bacterial adhesion. In: Savage DC, Fletcher M (eds) Bacterial adhesion, mechanism and physiological significance. New York, Plenum Press 1985: 3-43.

8. Khoury T, Costerton JW. Biofilm in nature and medicine. In : Peterson PK, Fleer A (eds) 3rd ECCM symposium on foreign body-related infections. Amsterdam, Excerpta Medica. 1987: 2-15.

9. Hussain M, Hastings JGM, White PJ. Isolation and composition of the extracellular slime made by coagulase- when EC was labelled with ${ }^{14} \mathrm{C}$ glucose compared to when the ${ }^{14} \mathrm{C}$ amino acid mixture was used; in the latter case the alanine spot showed most counts. On paper chromatograms the amounts of radioactivity counted in each constituent monomer were not in simple molar ratio as was previously detected by the chemical analyses. Labelled and unlabelled constituent monomers from differing precursors may be present in the isolated polymer.

Teichoic acid has been previously detected in culture supernate and in purified EC..$^{34,35,13}$ In the present study teichoic acid and proteins were detected in culture filtrate and material isolated from bacterial walls. CNS cell walls and membranes contain a glycerol teichoic acid. ${ }^{36}$ The presence of glycerol teichoic acid in EC preparations in this study and in the previous reports indicate the presence of teichoic acid in extracellular high-mol.-wt material.

It is clear that in our chemically-defined medium most of the extracellular polymeric material is teichoic acid. Whether teichoic acid alone is responsible for adherence is less certain. The material is water soluble and might remain close to the organisms that produce it only when the bacteria grow on a relatively dry surface. Furthermore, strains that are non-adherent make quantities of extracellular teichoic acid almost as great as that made by adherent strains. ${ }^{33}$ It is possible that protein or some minor extracellular polymer is the primary adhesin.

This work was supported by a scholarship awarded to $\mathrm{MH}$ from the Government of Pakistan.

negative staphylococci in a chemically defined medium. $J$ Infect Dis 1991; 163: 534-541.

10. Kloos WE, Schleifer KH. Simplified scheme for routine identification of human Staphylococcus species. J Clin Microbiol 1975; 1: 82-88.

11. Hussain M, Hastings JGM, White PJ. A chemically defined medium for slime production by coagulase-negative staphylococci. J Med Microbiol 1991; 34: 143-147.

12. Huff E, Oxley H, Silverman CS. Density-gradient patterns of Staphylococcus aureus cells and cell walls during growth and mechanical disruption. $J$ Bacteriol 1964; 88: $1155-1162$.

13. Yoshida AC, Heden CG, Cedregren B, Edebo L. A method for the preparation of undigested bacterial cell walls. $J$ Biochem Microbiol Technol Eng 1961; 3: 151-159.

14. Archibald AR, Baddiley J, Shaukat GA. The glycerol teichoic acid from walls of Staphylococcus epidermidis 12. Biochem $J$ 1968; 110: 583-588.

15. Block RJ, Durrum EL, Zweig G (eds) A manual of paper chromatography and paper electrophoresis, 2nd edn. New York, Academic Press. 1958: 171-214.

16. Jann B, Jann K, Müller-Seitz E. A 3-amino-3,6-dideoxyhexose from the lipopolysaccharide of Escherichia coli 071 . Nature 1967; 215: 170-171.

17. Dawson RMC, Elliott DC, Elliott WH, Jones KM (eds) Methods for the detection of biochemical compounds on paper and thin layer chromatograms, with some notes on separation. In: Data for Biochemical Research, 2nd edn. Oxford, The Clarendon Press. 1969: 509-591.

18. Sturgeon RJ. Enzymic determination of D-glucose, D-fructose and D-mannose. In: Whistler RL, Miller JN (eds) Methods in carbohydrate chemistry, vol 8. London, Academic Press. 1980: 135-139.

19. Bergmeyer HU, Bernt E. Glucose; determination with glucose oxidase and peroxidase. In: Bergmeyer HU (ed) Methods 
of enzymatic analysis vol 3. London, Academic Press. 1974: 1205-1211.

20. Lang G. L-(-)-Glycerol 3-phosphate. In: Methods of enzymatic analysis, $3 \mathrm{rd}$ edn, vol 6 . Weinheim, Verlag Chemie. 1984: 525-531.

21. Work E. Cell walls. Methods Microbiol 1971; 5A: 361-418.

22. Dubois M, Gilles KA, Hamilton JK, Reabers PA, Smith F. Colorimetric method for determination of sugars and related substances. Anal Chem 1956; 28: 350-356.

23. Dische $Z$, Shettles LB, Osnon M. New specific color reaction of hexoses and spectrophotometric micromethod for their determination. Arch Biochem 1949; 22: 169-184.

24. Devor AW. Carbohydrate tests using sulfonated $\alpha$-naphthol. $J$ Am Chem Soc 1950; 72: 2008-2012.

25. Herbert D, Phipps PJ, Strange RE. Chemical analysis of microbial cells. Methods Microbiol 1971; 5B: 209-344.

26. Levvy GA, McAllan A. The N-acetylation and estimation of hexosamines. Biochem J 1959; 73: 127-132.

27. Bitter T, Muir HM. A modified uronic acid carbazole reaction. Anal Biochem 1962; 4: 330-334.

28. Ames B. Assay of inorganic phosphorus, total phosphorus and phosphates. Methods Enzymol 1966; 8: 115-118.

29. Lowry OH, Rosebrough NJ, Farr AL, Randall RJ. Protein measurement with the Folin phenol reagent. J Biol Chem $1951 ; 193$ : 265-275.
30. Ben-Amotz A, Avron M. On the mechanism of osmoregulation in Dunaliella. In: Caplan SR, Ginzburg M (eds) Energetics and structure of halophilic microorganisms. Amsterdam, Elsevier. 1978: 529-541.

31. Rosen H. A modified ninhydrin colorimetric analysis for amino acids. Arch Biochem Biophys 1957; 67 : 10-15.

32. Stewart-Tull DES. Determination of amino sugars in mixtures containing glucosamine, galactosamine and muramic acid. Biochem J 1968; 109: 13-18.

33. Hussain M, Collins C, Hastings JGM, White PJ. Radiochemical assay to measure the biofilm produced by coagulase-negative staphylococci on solid surfaces and its use to quantitate the effects of various antibacterial compounds on formation of biofilm. J Med Microbiol 1992; 37: 62-69.

34. Ekstedt RD, Bernhard JM. Preparation and characterization of slime layer material produced by Staphylococcus aureus. Proc Soc Exp Biol Med 1973; 142: 86-91.

35. Tojo M, Yamashita N, Goldmann DA, Pier GB. Isolation and characterization of a capsular polysaccharide adhesin from Staphylococcus epidermidis. J Infect Dis 1988; 157: 713-722.

36. Schleifer KH. The cell envelope. In: Easmon CSF, Adlam C (eds) Staphylococci and staphylococcal infections vol 2. New York, Academic Press. 1983: 384-428. 